\title{
A Combined Strategy to Improve the Development of a Coral Antivenom Against Micrurus spp.
}

\author{
Karen Larissa Pereira de Castro ${ }^{1 \dagger}$, Letícia Lopes-de-Souza ${ }^{2 \dagger}$, Daysiane de Oliveira ${ }^{3}$, \\ Ricardo Andrez Machado-de-Ávila ${ }^{3}$, Ana Luiza Bittencourt Paiva ${ }^{4}$, Cláudio F. de Freitas ${ }^{4}$, \\ Paulo Lee $\mathrm{Ho}^{5}$, Carlos Chávez-Olórtegui ${ }^{2}$ and Clara Guerra-Duarte ${ }^{4 *}$ \\ ${ }^{1}$ Department of Biochemistry and Molecular Biology, University of Texas Medical Branch, Galveston, TX, United States, \\ ${ }^{2}$ Departamento de Bioquímica, Instituto de Ciências Biológicas, Universidade Federal de Minas Gerais, Belo Horizonte, \\ Brazil, ${ }^{3}$ Universidade de Extremo Sul Catarinense, Criciúma, Brazil, ${ }^{4}$ Fundação Ezequiel Dias, Belo Horizonte, Brazil, \\ ${ }^{5}$ Instituto Butantan, São Paulo, Brazil
}

OPEN ACCESS

Edited by:

Denise Doolan,

James Cook University, Australia

Reviewed by:

Juan J. Calvete,

Spanish National Research Council

(CSIC), Spain

Sofia A. Casares,

Naval Medical Research Center,

United States

*Correspondence: Clara Guerra-Duarte claragd@gmail.com

tThese authors have contributed equally to this work

Specialty section:

This article was submitted to Vaccines and Molecular Therapeutics,

a section of the journal

Frontiers in Immunology

Received: 28 May 2019

Accepted: 27 September 2019

Published: 21 October 2019

Citation:

de Castro KLP, Lopes-de-Souza L, de Oliveira D, Machado-de-Ávila RA,

Paiva ALB, de Freitas CF, Ho PL,

Chávez-Olórtegui $C$ and

Guerra-Duarte C (2019) A Combined Strategy to Improve the Development of a Coral Antivenom Against Micrurus spp.. Front. Immunol. 10:2422. doi: 10.3389/fimmu.2019.02422
Accidents involving Micrurus snakes are not the most common ones but are noteworthy due to their severity. Victims envenomed by Micrurus snakes are at high risk of death and therefore must be treated with coral antivenom. In Brazil, the immunization mixture used to fabricate coral antivenom contains Micrurus frontalis and Micrurus corallinus venoms, which are difficult to be obtained in adequate amounts. Different approaches to solve the venom limitation problem have been attempted, including the use of synthetic and recombinant antigens as substitutes. The present work proposes a combined immunization protocol, using priming doses of $M$. frontalis venom and booster doses of synthetic B-cell epitopes derived from $M$. corallinus toxins (four three-finger toxins-3FTX; and one phospholipase $\mathrm{A}_{2}-\mathrm{PL} \mathrm{A}_{2}$ ) to obtain coral antivenom in a rabbit model. Immunized animals elicited a humoral response against both $M$. frontalis and $M$. corallinus venoms, as detected by sera reactivity in ELISA and Western Blot. Relevant crossreactivity of the obtained sera with other Micrurus species (Micrurus altirostris, Micrurus lemniscatus, Micrurus spixii, Micrurus surinamensis) venoms was also observed. The elicited antibodies were able to neutralize $\mathrm{PLA}_{2}$ activity of both $M$. frontalis and $M$. corallinus venoms. In vivo, immunized rabbit sera completely protected mice from a challenge with 1.5 median lethal dose $\left(L D_{50}\right)$ of $M$. corallinus venom and $50 \%$ of mice challenged with $1.5 \mathrm{LD}_{50}$ of $M$. frontalis venom. These results show that this combined protocol may be a suitable alternative to reduce the amount of venom used in coral antivenom production in Brazil.

Keywords: antivenom, synthetic peptides, Micrurus, snake, epitopes, three-finger toxins, phospholipase $A_{2}$

\section{INTRODUCTION}

Snakebite is a worldwide health problem, considered by the World Health Organization (WHO) as a neglected tropical disease (1). Almost 3 million snake envenomings, with 81,000-138,000 deaths, are officially reported per year. However, since most accidents occur in poor rural areas often devoid of medical care and proper data registry, this number is thought to be largely underestimated (2). 
In Brazil, four genera are responsible for the medically relevant accidents: Bothrops, Crotalus, Lachesis, and Micrurus (3). Among them, elapid envenomation caused by snakes from the genus Micrurus are not the most common ones, but are noteworthy due to their severity, as more than $26 \%$ of the cases are considered to be severe (in bothropic accidents, the most prevalent ones, severe accidents correspond to only $7 \%$ of the cases) (4).

In human accidents caused by Micrurus snakes, there is substantial risk of neuromuscular blockage, with paralysis and respiratory failure leading to death. Even patients admitted with mild symptoms or even completely asymptomatic can progress to paralysis in a short time interval (5). Therefore, the treatment protocol recommended by the Brazilian Ministry of Health states that all victims of elapid accidents must receive 10 ampoules of coral antivenom, regardless of the severity of the initial symptoms presented (6).

Brazilian coral antivenom is produced from horse hyperimmunization with venom from the two species responsible for most accidents (7): Micrurus frontalis and Micrurus corallinus; but at least 33 other species are described in the country (8). Venom availability is an important bottleneck for antivenom production, since Micrurus snakes are relatively small, with reduced venom glands and lower venom yields compared to other snakes. While Bothrops snakes give around $80 \mathrm{mg}$ of venom per milking, Micrurus venom yield is considerably lower. The amount of venom that can be extracted from a Micrurus snake can vary greatly depending on the species. It ranges from $3 \mathrm{mg}$ for $M$. corallinus to $54 \mathrm{mg}$ per milking in M. suranimensis, but venom yield average rarely exceeds $20 \mathrm{mg}$ (7-10). Also, M. corallinus is a species particularly sensitive to captivity, with important dietary restrictions and disease susceptibility. Moreover, the acquisition of new snake specimens by antivenom producers animal husbandry has decreased over time, since it has been more difficult to find them in nature due to their fossorial habits and reduction of their natural habitat $(9,11)$.

Research efforts have been made to overcome these problems in coral antivenom production. Better animal management (11), strategies to enhance collected venom yields (9) and even a suggestion of using cross-neutralizing antivenom obtained from other species of Elapidae snakes (12) were proposed.

Another approach to address this problem is the use of synthetic substitutes to $M$. corallinus venom. In 2009, Leão and collaborators indicated some candidate molecules from its venom gland transcriptome analysis to represent $M$. corallinus venom in antivenom production. The toxin selection was based on abundance and representative variability. Three-finger toxins (3FTX) and phospholipases A2 (PLA2) accounted for more than $85 \%$ of the toxins expressed. Thus, cDNAs corresponding to four diverse 3FTXs and one PLA2 were applied in a preliminary immunization protocol. The selected antigens could induce specific antibodies, although venom recognition by the generated antibodies in ELISA was low (13).

Using the same five toxins from $M$. corallinus venom selected by Leão et al. (13), Castro et al. (14) performed epitope mapping of these antigens by SPOT technique and bioinformatic analysis. The combination of the mapping approaches of these five antigens resulted in the selection of nine sequences corresponding to putative epitopes, which were chemically synthesized. A mixture of these synthetic peptides was used to immunize rabbits. Anti-peptides antibodies were capable of neutralizing phospholipase A2 and lethal activities of $M$. corallinus venom, validating the potential application of these synthetic molecules in antivenom production. Ramos et al. (15) also used the antigens defined by Leão et al. (13) to map epitopes and proposed a genetic immunization protocol using DNA-strings and a multiepitopic protein. Serum derived from the genetic immunization protected mice challenged with $M$. corallinus venom.

Considering all previous efforts described above, the present work proposes a combined immunization protocol to produce a bivalent coral antivenom, using crude $M$. frontalis venom and substituting $M$. corallinus venom for the synthetic peptides validated by Castro et al. (14).

\section{MATERIALS AND METHODS}

\section{Animals and Venoms}

Micrurus sp. venoms were kindly provided by Ezequiel Dias Foundation (FUNED): $M$. frontalis, $M$. corallinus, $M$. lemniscatus, M. altirostris and by Instituto National de Salud (Peru): M. spixii, M. surinamensis. Snakes' subspecies of the obtained venom samples were not specified by the donors. Lyophilized venoms were stored at $-20^{\circ} \mathrm{C}$ in the dark. Prior to use, venoms were dissolved in ultra-pure water and protein content was determined by Lowry method (16), using bovine serum albumin as standard.

Female Swiss mice (18-22 g) and New Zealand female rabbits $(2 \mathrm{~kg})$ were maintained in Centro de Bioterismo of Instituto de Ciências Biológicas of Universidade Federal de Minas Gerais (UFMG), Brazil. All animals received food and water ad libitum under controlled environmental conditions.

This study was carried out in accordance with the principles of the Basel Declaration and recommendations of the Brazilian Council for the Control of Animal Experimentation (CONCEA). The protocol was approved by the Ethics Committee in Animal Experimentation from the Federal University of Minas Gerais (protocol 375/2012-CETEA/UFMG).

\section{Synthesis of Soluble Peptides}

Epitope sequences mapped in the work of Castro et al. (14) (39PDDFTCVKKWEGGGRRV55, from 3FTX Mcor0100c, named Pep100; 37TCPAGQKICFKKWKKG52 and 64PKPKK DETIQCCTKNN79, from 3FTX Mcor0039c, named Pep039a and Pep039b, respectively; 22LECKICNFKTCPTDELRH39 and 54THRGLRIDRGCAATCPTVK72 from 3FTX Mcor0604c, named Pep604a and Pep604b; 28RHASDSQTTTCLSGICYKK45 and 58GCPQSSRGVKVDCCMRDK75, from Mcor0599c, named Pep599a and Pep599b, respectively and peptides 28NLIN FQRMIQCTTRRSAW45 and 119NCDRTAALCFGRAPYN KNN137, from McorPLA2, named PepPLA2a and Pep- PLA2b) were synthesized by the Fmoc chemistry method on an automatic Multipep robot (Intavis). All internal cysteine residues were replaced by serines and a tyrosine was added to the $\mathrm{N}$-terminus of 
the sequences which did not possess aromatic residues (Pep039b, Pep604a and b, and Pep599b) in order to allow quantification of peptides by absorbance at $280 \mathrm{~nm}$. During the synthesis, peptides were immobilized on Rink Amide resin (Novabiochem). At the end of the synthesis, peptides were released from the resin, and side chain deprotection was carried out by trifluoroacetic acid treatment (95\% TFA, 2.5\% triisopropylsilane, and 2.5\% water). All peptides were N-terminally acetylated and C-terminally amidated. After synthesis, peptides were lyophilized, and their purity was assessed by mass spectrometry in system MALDI-TOF/TOF (Autoflex III e Bruker Daltonics Inc.). The experimentally measured peptide masses differed from the theoretically expected by $1.012 \mathrm{Da} \pm 0.658$ on average, indicating good synthesis quality.

\section{Immunization Protocols}

Adult New Zealand female rabbits were immunized as a proof-of-concept of the proposed immunization protocol for coral antivenom production (Figure 1A). After collection of non-immune sera, animals received an initial subcutaneous injection of $200 \mu \mathrm{g}$ of $M$. frontalis crude venom in complete Freund's adjuvant (day 1). Two booster injections were made subcutaneously at intervals of 2 weeks with the same dose $(200$ $\mu \mathrm{g})$ of $M$. frontalis venom in incomplete Freund's adjuvant. Two weeks after that, rabbits received three subcutaneous injections of $450 \mu \mathrm{g}$ of the mixture of all synthetic peptides (Figure 1B) $(50 \mu \mathrm{g}$ of each peptide) in incomplete Freund's adjuvant, also at intervals of 2 weeks. Blood samples were drawn 1 week after each injection. After a break of 60 days, rabbits received six additional doses of $450 \mu \mathrm{g}$ of the mixture of all peptides in Montanide adjuvant at intervals of 2 weeks. Blood samples were drawn 1 week after the last injection.

\section{IgG Purification}

IgGs were purified from immunized rabbit's sera. Serum IgGs were concentrated by precipitation with ammonium sulfate and purified by affinity chromatography using a Protein A-Sepharose column (GE Healthcare), according to the protocol described by the GE Healthcare Bio-Sciences AB.

\section{Indirect ELISA Assays}

Microtitration plates (Costar, USA) were coated overnight with either $0.5 \mu \mathrm{g} /$ well of Micrurus venoms at $4^{\circ} \mathrm{C}$ or $1.0 \mu \mathrm{g} /$ well of glutaraldehyde polymerized peptides at $37^{\circ} \mathrm{C}$ in carbonate buffer $\mathrm{pH}$ 9.6. After blocking (3\% skimmed milk in PBS) and washing $(0.05 \%$ Tween-saline), non-immune rabbit sera or immune sera were added in different dilutions and incubated for

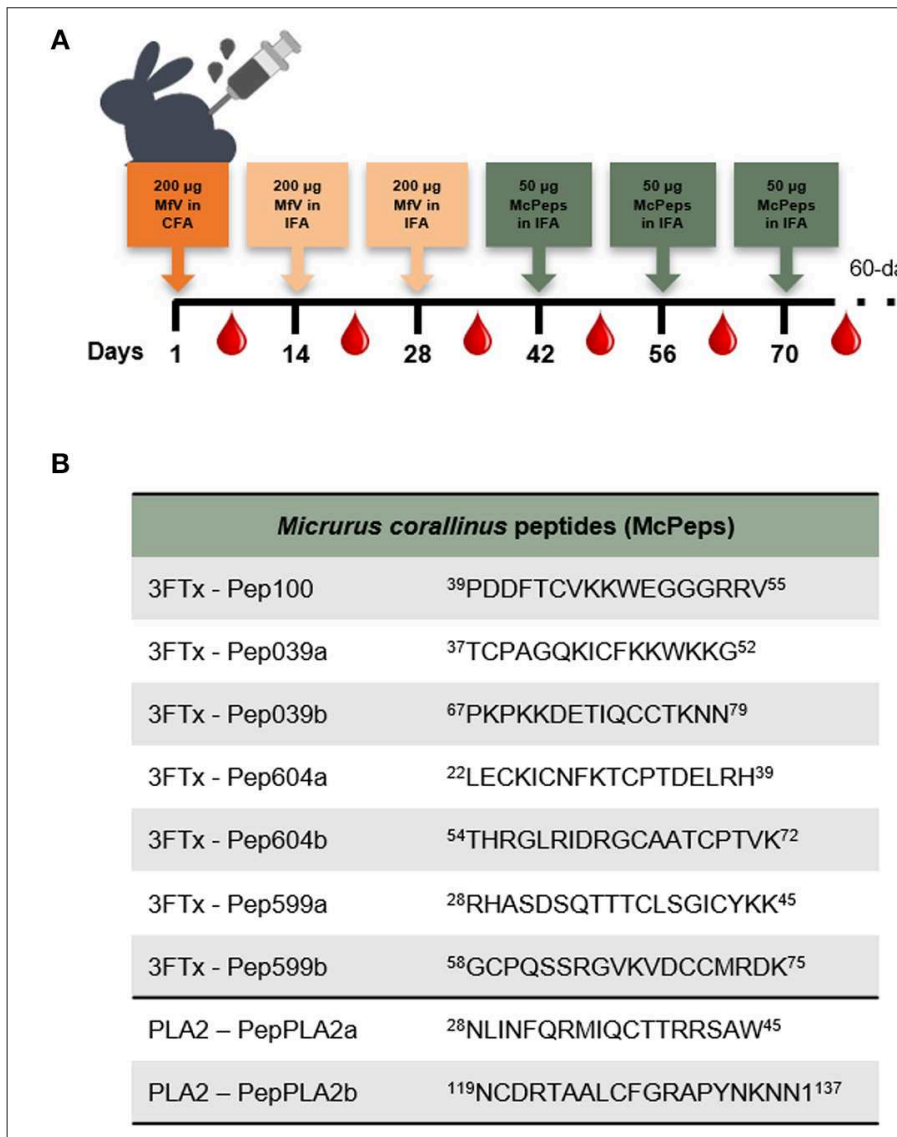

FIGURE 1 | Immunization protocol. (A) Rabbits immunization scheme for coral antivenom alternative production. Doses were given at 2-week intervals with the immunogen described in the boxes above the line. Bleedings were performed 1 week after each dose, as signaled. (B) Peptides sequences derived from epitope prediction of Micrurus corallinus toxins, made by Castro et al. (14) used in the immunization protocol. 
$1 \mathrm{~h}$ at $37^{\circ} \mathrm{C}$. Plates were washed and incubated with anti-rabbit IgG conjugated with peroxidase (Sigma, USA) diluted 1:10,000, for $1 \mathrm{~h}$ at $37^{\circ} \mathrm{C}$. After washing, OPD Peroxidase substrate (SIGMAFAST from Sigma-Aldrich) was added to the wells. The reaction was interrupted after 30 min using $20 \mu \mathrm{l}$ of a 1:20 sulfuric acid solution. Absorbance values were determined at $490 \mathrm{~nm}$ using an ELISA plate reader (BIO-RAD, iMark models, EUA). Values represent the mean of two independent experiments.

\section{Western Blotting}

Micrurus venoms were diluted in sample buffer under reducing conditions and SDS-PAGE was performed on $18 \%$ polyacrylamide gels. Protein bands were visualized by silver staining or transferred to nitrocellulose membranes for immunoblotting.

For western blot, gels were wet-transferred to nitrocellulose membranes overnight. The membrane was blocked with PBS-Tween $0.3 \%$ for $1 \mathrm{~h}$. After washing three times for 5 min with PBS-Tween $0.05 \%$, the membrane was incubated with either rabbit non-immune serum, immunized rabbit sera or commercial coral antivenom produced by FUNED, diluted 1:2,000 for $1 \mathrm{~h}$. The membrane was washed (PBSTween $0.05 \%$ ) three times and immunoreactive proteins were detected using anti-rabbit or anti-horse IgGs conjugated to peroxidase for $1 \mathrm{~h}$ at $37^{\circ} \mathrm{C}$. After additional washes, reaction was detected using $\mathrm{DAB} /$ chloronaphthol substrate, according to the manufacturer's instructions.

\section{Phospholipase A2 Activity Determination}

To analyze PLA2 activity, EnzChek ${ }^{\circledR}$ PLA2 Assay Kit (Life Technologies) was used. The experiment was made following EnzCheck's protocol, using $2 \mu \mathrm{g}$ of either $M$. frontalis or $M$. corallinus venom. A solution of PLA2 $10 \mathrm{U} / \mathrm{mL}$ in $1 \times$ PLA2 reaction buffer was used as positive control and the same buffer without PLA2 was used as negative control. All assays were performed in duplicates. Means of the results from two independent experiments were calculated and plotted as percentage of activity, relative to the positive control.

\section{Neutralization Assays}

\section{Neutralization of Phospholipase Activity}

PLA2 activity was determined using an indirect hemolytic assay described by Gutiérrez et al. (17). Samples with increasing concentrations of either $M$. frontalis or $M$. corallinus venom were prepared in a final volume of 15 microliters in PBS and added to $3 \mathrm{~mm}$ wells in agarose gels $(0.8 \%$ in phosphate buffered saline, $\mathrm{pH} 8.1$ ) containing $1.2 \%$ rabbit erythrocytes, $1.2 \%$ egg yolk as a lecithin source and $100 \mathrm{mM}$ of $\mathrm{CaCl} 2$. After incubation at $37^{\circ} \mathrm{C}$ for $18 \mathrm{~h}$ in a wet chamber, hemolytic halos were measured. Then, the minimum phospholipase dose (MPD: the minimum concentration of venom which produced a hemolytic halo of $1 \mathrm{~cm}$ of diameter) was determined.

For assessing the PLA2 neutralizing potential of rabbits' IgG's, increasing concentrations of IgGs were pre-incubated with 1 MPD of either $M$. frontalis or $M$. corallinus crude venom at $37^{\circ} \mathrm{C}$ for $1 \mathrm{~h}$ and added to the $3 \mathrm{~mm}$ wells in agarose. The assay proceeded as described above. As controls, non-immune
IgGs were incubated with venoms $(\mathrm{C}+)$ and a pool of IgG was incubated with PBS (C-).

\section{Neutralization of Lethal Activity}

For in vivo neutralization assays, 3 groups of 4 mice were used for each venom. Animals were injected intraperitoneally with 500 $\mu \mathrm{l}$ of a solution containing a dose corresponding to 1.5 LD50 of either M. frontalis (33 $\mu \mathrm{g} / 20 \mathrm{~g}$ mouse) or M. corallinus (10.5 $\mu \mathrm{g} / 20 \mathrm{~g}$ mouse) venom, pre-determined by Tanaka et al. (18) in PBS-BSA $0.1 \%$, pre-incubated for $1 \mathrm{~h}$ at $37^{\circ} \mathrm{C}$ with either with $100 \mu \mathrm{l}$ of a pool of sera from immunized rabbits, $100 \mu \mathrm{l}$ coral antivenom or $100 \mu \mathrm{l}$ of PBS. Dead animals were counted $48 \mathrm{~h}$ after the challenge.

\section{RESULTS}

\section{Immunocharacterization of Elicited Antibodies}

To overcome difficulties in producing bivalent coral antivenom, we propose a combined protocol, using crude $M$. frontalis venom and synthetic peptides derived from $M$. corallinus toxins sequences. Two rabbits were immunized using the immunogen combination, as a proof-of-concept. The produced sera will be further named as anti-Ven $\mathrm{V}_{\text {fro }} / \mathrm{Pep}_{\mathrm{cor}}$, referring that the elicited antibodies are directed against crude venom of $M$. frontalis and peptides derived from toxin's sequences of $M$. corallinus.

Antibody reactivity of anti- $\mathrm{Ven}_{\mathrm{fro}} / \mathrm{Pep}_{\mathrm{cor}}$ sera was assayed with both Micrurus venoms by ELISA, after each immunization dose given to animals (Figures 2A,B). Results show that the proposed immunization protocol induced antibodies able to recognize $M$. frontalis and $M$. corallinus venoms in both rabbits, although serum from rabbit 2 showed weaker binding to $M$. corallinus venom (Figure 2A). The first three doses in the protocol used crude $M$. frontalis venom. Therefore, the immune response against this venom increased more rapidly (after the 2 nd dose) than against $M$. corallinus. On the other hand, antibody reactivity against $M$. corallinus continued to increase throughout the immunization protocol, whereas reactivity against $M$. frontalis plateaued after the 4th dose, with a slight increase after the 12th dose for serum 1 . It is relevant to mention that $M$. corallinus peptides booster doses were able to keep serum reactivity against $M$. frontalis, even in the absence of this venom as antigen in the subsequent doses.

After the 12 th dose, anti- $\mathrm{Ven}_{\text {fro }} / \mathrm{Pep}_{\text {cor }}$ sera were titrated against both venoms (Figures 2C,D). Antibody titers against $M$. corallinus were lower than against $M$. frontalis. Sera from rabbit 1 and 2 showed different reactivities against $M$. corallinus and were more homogenous against $M$. frontalis. However, both animals produced a satisfactory response against both venoms.

To further characterize the antigenicity of the peptides used in the immunization protocol, anti-Ven $\mathrm{V}_{\text {fro }} / \mathrm{Pep}_{\text {cor }}$ sera reactivity against each individual peptide was also assessed. Except for Pep599a, all peptides were well recognized by both sera. Serum from rabbit 1 and rabbit 2 also presented similar reactivity against all peptides, with a marked difference detected only for PepPLA2a (Figure 3). 

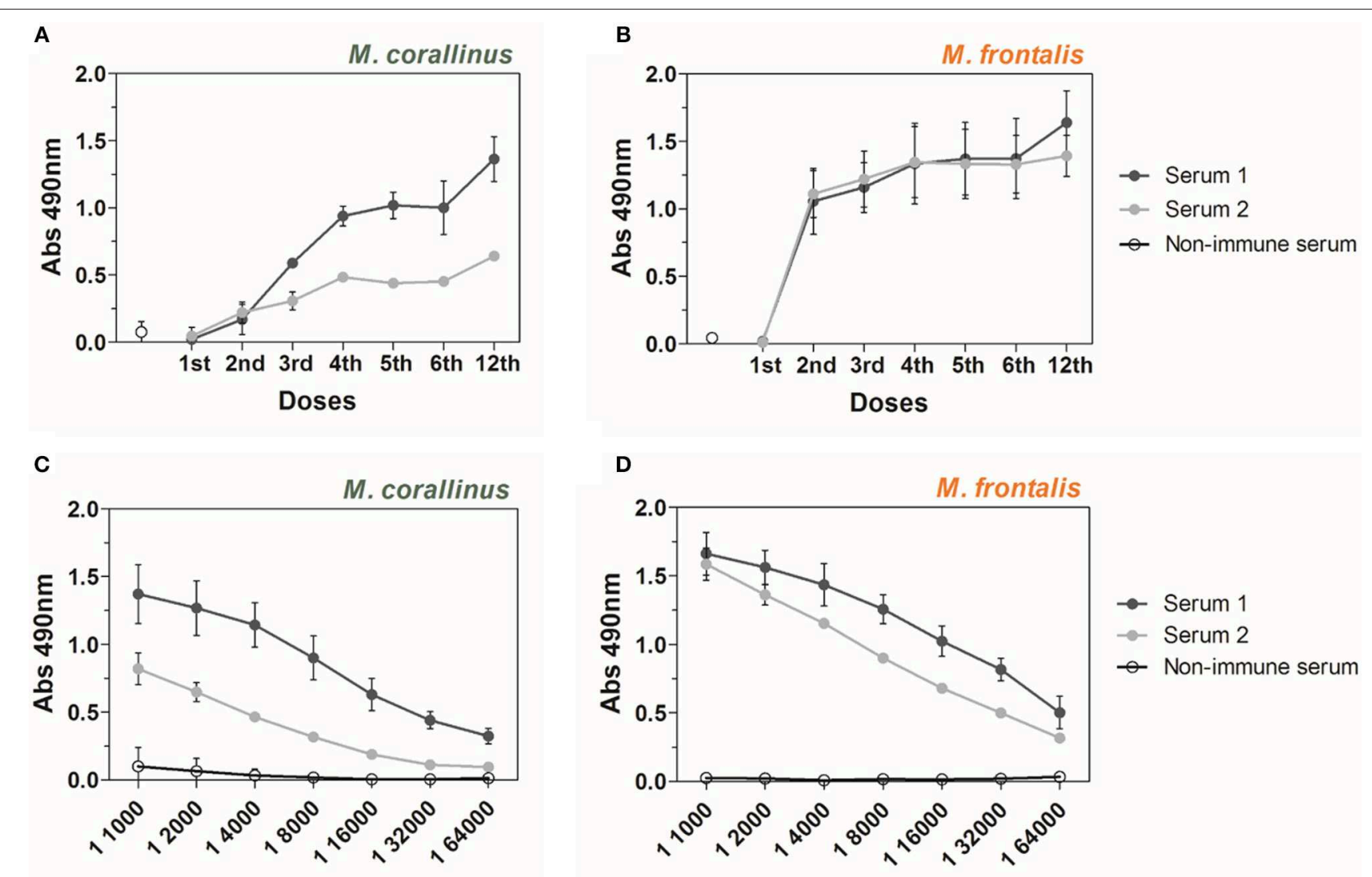

Sera dilution

D

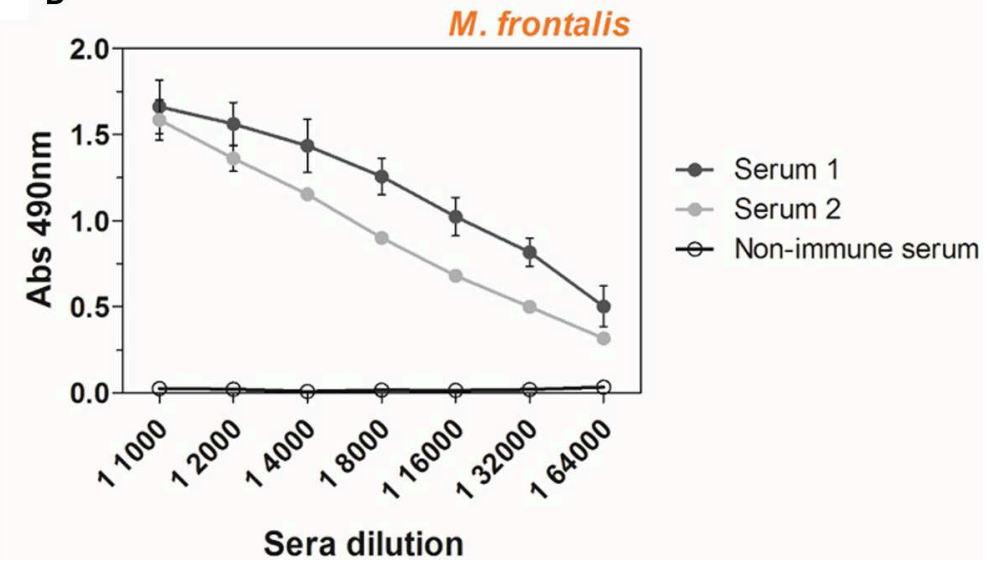

FIGURE 2 | ELISA reactivity of anti-Ven fro $/$ Pep $_{\text {cor }}$ sera against $M$. corallinus and $M$. frontalis venoms. Graphs show ELISA reactivity of rabbit 1 and 2 anti-Ven fro $/$ Pep sera (Serum 1 and serum 2) against (A) $M$. corallinus venom and (B) $M$. frontalis venom. Plates were coated with $0.5 \mu \mathrm{g} /$ well of each venom and incubated with sera of different immunization doses. Sera obtained after 12th dose were titrated (1:1,000-1:64,000) against (C) $M$. corallinus venom and (D) $M$. frontalis venom. Anti-horse peroxidase (1:10,000) was used as secondary antibody and Sigma OPD tablets detected recognition, according to manufacturer's instructions. Non-immune serum was used as negative control. Values are means \pm SD of two independent experiments.

\section{Cross-Reactivity of Produced Sera With Other Micrurus Venoms}

Along with $M$. corallinus and $M$. frontalis, other species from Micrurus genus also occur in Brazil. Since the precise identification of the exact species of the offender snake is rarely made, all elapid accidents are treated with the same antivenom. Therefore, it is relevant to test cross-reactivity of the produced

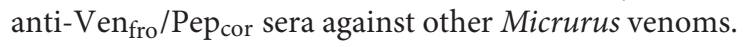

In an ELISA assay, M. lemniscatus and M. spixii showed considerable cross-reactivity, being more strongly or equally recognized by anti- $\mathrm{Ven}_{\text {fro }} / \mathrm{Pep}_{\text {cor }}$ sera of both rabbits than $M$. corallinus. $M$. altirostris and $M$. surinamensis, showed a weaker, yet remarkable reactivity with both sera (Figure 4).

A Western Blot assay was also performed to characterize the immunoreactivity of anti-Ven $\mathrm{fro}_{\text {fo }} / \mathrm{Pep}_{\text {cor }}$ sera against several Micrurus venoms and compare them with the approved therapeutical bivalent coral antivenom produced by FUNED (Figure 5). As verified in the ELISA assays, serum from rabbit 1 showed a slightly more intense reaction with the venoms. FUNED coral antivenom reacted with bands above
$38 \mathrm{KDa}$ more intensely than the produced anti-Ven $\mathrm{fro}_{\mathrm{fo}} / \mathrm{Pep}$ cor rabbit sera.

Toxins and mapped epitope sequences were aligned to other Micrurus 3FTx (Figures 6A-D) and PLA2 (Figure 6E) toxins available at UniProt to verify sequence similarities that could explain the sera cross-reactivities verified with the tested venoms. The alignments showed that not only toxins from the tested venoms but also from other Micrurus species have similar regions, ranging from 100 to $50 \%$ of identity, that can potentially explain cross-reaction of these venoms with anti-Ven $\mathrm{fro}_{\mathrm{fro}} / \mathrm{Pep}_{\mathrm{cor}}$ sera (Figures 6, 7). Pep100 and Pep604a did not show significant similarity to other Micrurus toxins and seems to be exclusive to M. corallinus venom.

\section{Neutralization Assays}

Reactivity of the produced anti-Ven $\mathrm{fro}_{\mathrm{fro}} / \mathrm{Pep}_{\mathrm{cor}}$ sera toward different Micrurus venoms was well established using different techniques. However, antibody in vitro reactivity not always means efficient neutralization of toxic venom activities. To this 
end, neutralization assays of PLA2 activity and lethality were performed for $M$. frontalis and $M$. corallinus venoms.

First, PLA2 basal activity of both venoms was determined by a fluorometric (Figure 7) and by indirect hemolytic assays (Figure 8). M. frontalis showed stronger PLA2 activity in both methodologies. Two micrograms of $M$. frontalis venom matched positive control activity of $100 \%$, even exceeding it a little, whereas $M$. corallinus barely achieved $40 \%$ of the C+ activity in the fluorometric assay.

The PLA2 neutralizing potential of the produced antibodies was tested in the indirect hemolytic assay, using different amounts of IgGs purified from anti-Ven fro $_{\text {fep }} / p_{\text {cor }}$ sera (6-0.375 $\mu \mathrm{g}$ ) (Figure 8) incubated with 1 minimum phospholipase dose (MPD). This dose was established previously (14) for each venom: $M$. frontalis was $0.022 \mu \mathrm{g}$ of venom and $1.84 \mu \mathrm{g}$ for $M$. corallinus (almost 85-times less active than $M$. frontalis).

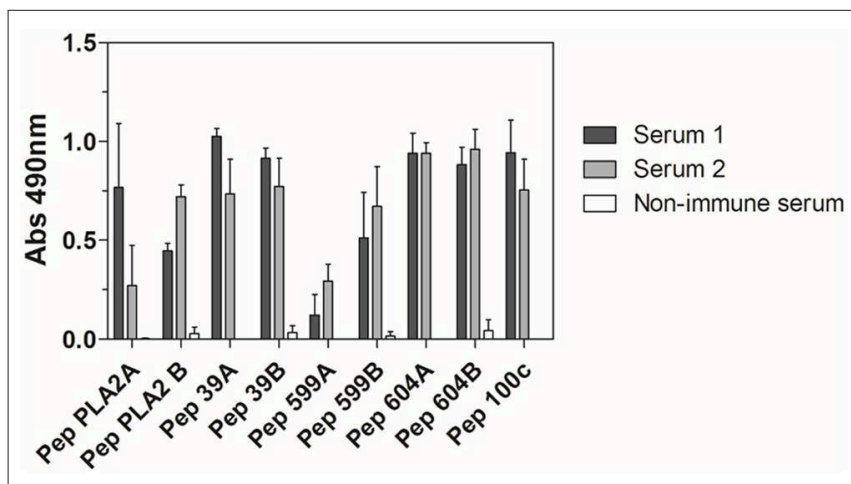

FIGURE 3 | ELISA reactivity of anti-Ven $\mathrm{fro}_{\text {fro }} / \mathrm{Pep}_{\text {cor }}$ sera against $M$. corallinus peptides. Rabbit sera after 12th dose (diluted 1:100) were tested against individual peptides coated to ELISA plates (10 $\mu \mathrm{g} /$ well). Anti-horse peroxidase $(1: 10,000)$ was used as secondary antibody and Sigma OPD tablets detected recognition, according to manufacturer's instructions. Non-immune serum was used as negative control. Values are means \pm SD of two independent experiments.
We used purified IgGs instead of serum to avoid interference of other serum components in the assay. Phosphate buffer incubated with $6 \mu \mathrm{g}$ of anti-Ven $\mathrm{fro}_{\text {fro }} / \mathrm{Pep}_{\text {cor }}$ IgGs was used as negative control and $1 \mathrm{MPD}$ of each venom incubated with 6 $\mu \mathrm{g}$ of non-immune IgG was used as positive control. Consistent with its higher phospholipase activity, M. frontalis venom was less efficiently neutralized by anti-Ven $\mathrm{fro}_{\text {fro }} / \mathrm{Pep}_{\text {cor }}$ IgGs, achieving $100 \%$ inhibition only with the higher concentration of IgG tested. Contrary to what was observed in the immunocharacterization assays, IgGs from rabbit 2 seems to have a higher PLA2 neutralization potential than those from rabbit 1, confirming that antibody recognition of a given antigen does not mean necessarily antibody neutralization.

For the in vivo lethality neutralization (Table 1), we used 100 $\mu \mathrm{l}$ of a pool of both rabbits' sera incubated for $1 \mathrm{~h}$ at $37^{\circ} \mathrm{C}$ with an amount of venom equivalent to 1.5 LD50 of each Micrurus venom. Bivalent coral antivenom from FUNED was used as a positive control and PBS as a negative control. As expected, FUNED's antivenom fully protected animals from the venom challenge with both venoms, and the dose of 1.5 LD50 of both venoms incubated only with PBS killed $100 \%$ of injected mice. Anti-Ven fro $_{\text {fep }} / \mathrm{Per}_{\text {cor }}$ sera showed to have lethality neutralization potential and fully protected animals from the challenge with $M$. corallinus venom. However, $M$. frontalis venom was less efficiently neutralized by anti-Ven $\mathrm{n}_{\text {fro }} / \mathrm{Pep}_{\text {cor }}$ sera, that protected only $50 \%$ of challenged animals. The assay was initially made with four animals. To confirm the difference of protection between $M$. corallinus and $M$. frontalis venom, the assay was repeated only for anti-Ven $\mathrm{fro}_{\mathrm{fr}} / \mathrm{Pep}_{\mathrm{cor}}$ sera and results were the same, indicating that indeed protection against $M$. corallinus venom lethality was higher when compared to $M$. frontalis venom.

\section{DISCUSSION}

Bites caused by snakes from the genus Micrurus represent $<1 \%$ of snakebite cases notified in Brazil, but most of the accidents are considered severe and antivenom administration
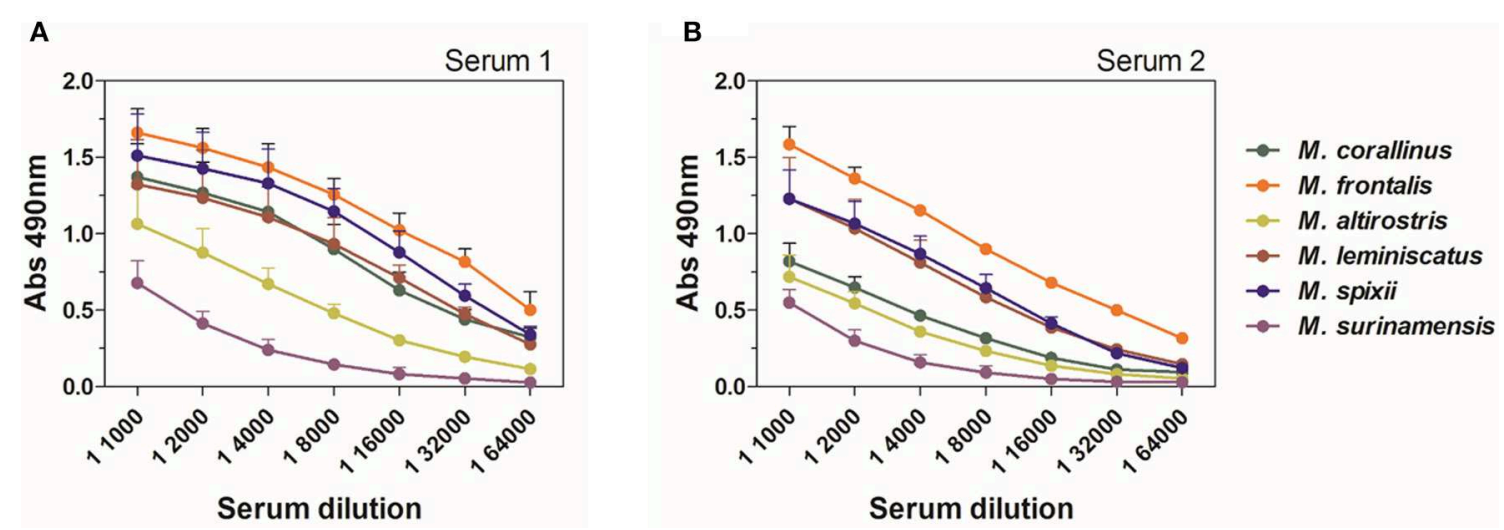

FIGURE 4 | ELISA cross-reactivity of anti-Ven fro $/ P_{\text {ep }}$ sera against Micrurus venoms. (A) Shows results for reactivity of serum from rabbit 1 and (B) shows results for rabbit 2. Plates were coated with $0.5 \mu \mathrm{g} /$ well of each Micrurus venom and incubated with different dilutions of rabbit sera after 12 th dose $(1: 1,000-1: 64,000)$. Anti-horse peroxidase (1:10,000) was used as secondary antibody and Sigma OPD tablets detected recognition, according to manufacturer's instructions. Non-immune serum was used as negative control. Values are means \pm SD of two independent experiments. 


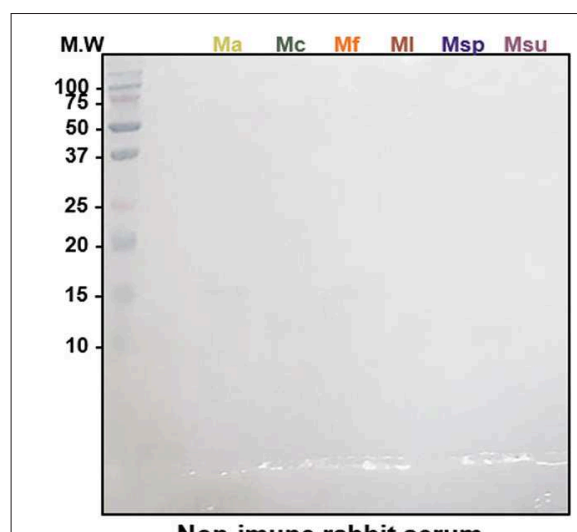

Non-imune rabbit serum (C-)

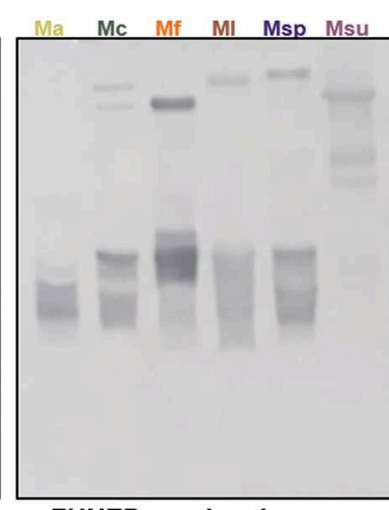

FUNED coral antivenom (C+)

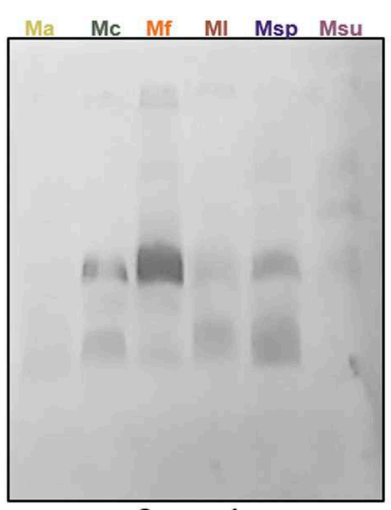

Serum 1

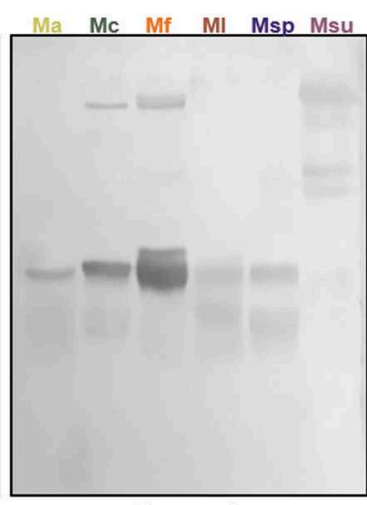

Serum 2

FIGURE 5 | Western blot analysis of anti-Ven fro $_{\text {Pep }}$ ( sera against Micrurus. Venoms (20 $\left.\mu \mathrm{g}\right)$ from M. altirostris (MaV), M. corallinus (McV), M. frontalis (MfV), M. leminiscatus (MIV), M. spixii (MspV), and M. surinamensis (MsuV) were submitted to SDS-PAGE 18\% under reducing conditions. Molecular size markers (MWM) are indicated in the left (in $\mathrm{kDa}$ ). Rabbit sera, including non-immune serum, and FUNED antivenom were diluted 1/2.000.

is recommended primarily in all cases (19). Antivenom shortage is a worldwide health problem (20) but Brazil stands as an exception, being self-sufficient in antivenom production (21-23). Nonetheless, the production of Brazilian coral antivenom specifically faces drawbacks and its production and quality control is limited, due to the difficulty in obtaining enough amounts of coral venom $(11,24,25)$.

To illustrate in figures the venom shortage in coral antivenom production, in the year of 2019, Ezequiel Dias Foundation (FUNED) has obtained until August a total of $133 \mathrm{mg}$ of venom from 11 specimens of $M$. frontalis kept in the Foundation's Serpentarium. However, to perform the immunization protocol for coral antivenom production to supply the yearly national demand, it is necessary at least $450 \mathrm{mg}$ of venom, considering the quality control tests. These numbers show that the amount of venom that has been obtained so far represents $<30 \%$ of the amount needed for the production of coral antivenom. Venom yield can vary from year to year depending on several factors, but there is a general consensus among Brazilian antivenom producing Institutions that Micrurus venom availability is almost always lower than the desirable. In Brazil, coral antivenom is produced by Ezequiel Dias Foundation (FUNED), in Minas Gerais state, and by Butantan Institute, in São Paulo state. It is produced using venoms from $M$. corallinus and $M$. frontalis species as immunogens. These venoms are mostly composed of three-finger toxins (3FTx) and phospholipase A2 (PLA2), which are considered the major responsible for the envenoming symptoms caused by coral snakes. As these toxins are capable of inducing polyclonal antibodies (13), our group has identified neutralizing B-cell linear derived from them. These epitopes selection was made using the SPOT technique. Overlapping pentadecapeptides covering $M$. corallinus toxin's sequences were synthesized in a cellulose membrane and probed with antiM. corallinus venom rabbit serum, FUNED and Butantan's coral antivenoms. The most reactive peptide sequences were selected, refined by immunoinformatics using the EPITOPIA epitope prediction tool (26) and used for rabbit immunization. This approach showed that synthetic peptides mimicking toxin's epitopes can improve the generation of antivenoms against coral snakes (14).

Building upon this previous approach, the present work proposes a new immunization protocol for Brazilian coral antivenom production, with a substantial reduction in the use of crude venoms, in a rabbit model. Three priming doses of $M$. frontalis venom and no $M$. corallinus venom at all would be necessary for this protocol, that was capable of eliciting neutralizing antibodies against these venoms. When compared to our previous work, which used only synthetic peptides as immunogens (14), the present protocol, using venom priming, showed an upgrade, achieving better antibody titers, neutralization potential and cross-reactivity. The produced anti-Ven $\mathrm{fro}_{\text {fro }} / \mathrm{Pep}_{\mathrm{cor}}$ sera could fully protect animals challenged with a lethal dose of $M$. corallinus venom from death, whereas the previously produced anti-peptide sera promoted half of this protection.

Another novelty of the present work was that neutralization properties of the experimental antivenom was also tested with M. frontalis venom. Anti-Ven $\mathrm{fro}_{\mathrm{fr}} / \mathrm{Pep}_{\mathrm{cor}}$ antibodies neutralized PLA2 activity of $M$. frontalis venom and promoted $50 \%$ lethality protection of animals challenged with this venom. The fact that M. frontalis venom was less neutralized by our experimental antivenom than $M$. corallinus venom is noteworthy, considering that ELISA reactivity suggests that the elicited antibodies recognize $M$. frontalis venom better than $M$. corallinus venom. One possibility to explain the lack of $M$. frontalis venom neutralization by Anti-Ven $\mathrm{fro}_{\mathrm{f}} / \mathrm{Pep}_{\mathrm{cor}}$ antibodies is the fact that, although we have used the amount related to $1.5 \mathrm{LD}_{50}$ for both venoms in the performed challenge, the absolute venom amounts used are not the same. We considered in the assay the intra peritoneal $\mathrm{LD}_{50}$ values published by Tanaka et al. (18), being the value for M. corallinus venom 7 and $22 \mu \mathrm{g}$ for 
A

\section{MCOr0100 (C6JUP3) IVCYTNVLEPPGTLETCPDDFTCVKKWEGGGRRVTQYCSHACAIPASYEFVHCCQTDKCNG}

No relevant epitope similarity with other toxins.

B

\begin{tabular}{|c|c|c|c|c|}
\hline \multirow{2}{*}{\multicolumn{2}{|c|}{ Mcor0039 (C6JUP0) TKCLTKFSPGLQTSQTCPAGQKICF-KKW--KKG----EKVSRGCAVTCPK-PKKDETIQCCTKNNCNR }} & \\
\hline & & & & \\
\hline Mful (U3FVH8) & TKCLTKFSPGLQTSQTTCPAGOKICF-KKW--KKG----KKVSRGCAVTCPK-PKKHETID̃CCTENNCNR & 951 & 100 & 88 \\
\hline ten (AOAOHAIUP1) & CLTKF SPGL QTSQTCPAGQKICF-KKW--KKG----KKVSRGCAVTCPK-PKKHES IQCCTENNCNR & & & 81 \\
\hline Mbro (AOAOHABEG5) & KKCLTKYSAGLQTSQTCPAGQKICF-KKW--KKG----EKVSRGCAVTCPK-PKKHETIQCCTENNCNR & 921 & 100 & 88 \\
\hline Mten (A0A194ARL8) & KKCLTKYSAGLQTSQTCPAGQKICF-KKW--KKG----EKVSRGCAVTCPK-PKKHETIDCCTENNCNR & 921 & & \\
\hline Mten (A0A194ARF2) & KKCLTKYSAGLQTSQTCPAGQKICF-KKW--KKG----EKVSRGCAVTCPK-PKKHETIQCCTENNCNR & & 100 & 88 \\
\hline Mten (A0A194API9) & KKCLTKYSAGLOTSOTCPAGOKICF-KKR--KKG----EKVSRGCAVTCPK-PKKHETIOCCTENNCNR & 90 & 94 & \\
\hline Mten (A0A194ATD7) & KKRITKYSAGLQTSQTCPAGQKICF-KKW--KKG----EKVSRGCAVTCPK-PKKHETIQCCTENNCNR & 90 & & 88 \\
\hline Malt (F5CPD1) & KKCLTKYSPGRETSQTCLAGQNICF-KKW--KKG----EKTSRGCAVTCPK-PKKDETIQCCTKNNCNR & 89 & 881 & 100 \\
\hline Mmip (A0A2P1BSS8) & RKCHTKNSPGRETSQACPT GQNICF-KKW--KKG----EIISKGCAVTCPK-PKKDETFQCCLKNNCNR & 79 & 81 & 88 \\
\hline Mten (A0A194ARB6) & RICLTDYSIFYETTETCPEGQNICI-KKF--PKGIPFLPWIIRGCAATCPK-RDRHTYIECCAADKCNR & 46 & 69 & 31 \\
\hline Mful (UзEPM9) & KTCYKYDTLFGKTTETCADGQNICF-KRW--HMLVPGRYHVSRGCAATCPK-AQNHDSVECCAKENCNA & 43 & 56 & 38 \\
\hline Mten (ADA194APF0) & KTCYKYDTLFGKTTETCADGQNICF-KRW--HMLAPGRYHVSRGCAATCPK-AQNHDSVECCAKENCNA & 43 & 56 & \\
\hline Msur (P86096) & LTCHTCPYNTCANSETCPAGKNICYQKKWEEHQG----ERIERRCVANCPKLGSNDKSLLCCRRDDCN- & 39 & 58 & 29 \\
\hline Msur (P86098) & LTCKTCPFNTCANSETCPAGKNICYOKKWEEHRG----ERIERRCVANCPKLGSNDKSLLCCRRDDCN- & 39 & 58 & 29 \\
\hline Msur (P86099) & LTCHTCPYNTCANSETCPAGKNICYOKKWEEHRG----ERIERSCVANCPEFESSHTSLICCTTANCD- & 39 & 58 & 35 \\
\hline
\end{tabular}

C

$$
\begin{aligned}
& .::^{*}::{ }^{*}{ }^{*} . \\
&
\end{aligned}
$$

\%ID

MCOR0604 (P58370) LECKICNFKTCPTDELRHCASGETICYKTFWNTHRGLRIDRGCAATCPTVKPGVNIICCKTDNCN- 100100100 Mfro (P86420) MIC--YNHQSSEPPTTKTCSEGQ--CYKKSWSDHRGTIIERGCA--CPNVKPGVKIICCRS--C-- 431163 Msur (P86095) MIC--YNQQSTEPPTTKTCSEGQ--CYKKTWSDHRGTIIERGCA--CPNVKPGVKISCCSSDKCR- $43 \quad 1163$

Malt (F5CPD5) MIC--YNQQSSQPPTTTTCSEGQ--CYKKTWSDHRGTIIERGCA--CPNVKPGVKISCCSSDKCNG $46 \quad 1163$

Mlat (K9MCH1) RIC--YNQQSSQPPTTKTCSEGQ--CYKKTWRDHRGTIIERGCA--CPNVKPGIQISCCTSDKCNG $44 \quad 1163$

Mbro (AOAOHAIVP) MIC--HNQQSSQPPTTITCSEGQ--CYRKFWSDHRGTIIERGCG--CPTVKPGIHISCCASDKCNA 441163

Mdia (AOA0G3YJD1) MIC--HNQQSS QPPTTKTCSEGQ--CYKKTWRDHRGTI IERGCG--CPTVKPGIHISCCASDKCNA $44 \quad 11 \quad 63$

Mten (A0A194ASE0) MIC--HNQQSSQPPTTKTCSEGQ--CYKKTWRDHRGTIIERGCG--CPTVKPDIHISCCTSDKCNA $42 \quad 1163$

Mten (A0A194ATBO) MIC--HNQQSSQPPTTKTCSEGQ--CYKKTWRDHRGTIIERGCG--CPTVKPGIHISCCTSDKCNA $44 \quad 1163$

Malt (F5CPE4) LIC--YNYETPLDKTTECCGNGVTTCFAKSWRDHRGLRTDRGCG--CPNVKPGVTINCCKTDRCNG $52 \quad 32 \quad 68$

Malt (F5CPD7) LIC--YNYWTPLDKTTECCGNGVTTCFAKSWNDHRGRRTDRGCG--CPNVKPGIHLNCCKTDRCNG $52 \quad 32 \quad 63$

Malt (F5CPD9) LIC--YNDHGFIGKTTETCENGMTTCYEKRWTEARGTRIDRGCG--CPNVKPGVNLNCCKTDRCNG $50 \quad 2263$

D

Seq PepA PepB Mcor (Q9PUB7) IVCYKRHASDSQTTTCLSGICYKKITRGISRPEMGCGCPQSSRGVKVECCMRDKCNG $97 \quad 10094$ MfUl (U3F5E9) ITCYKRHASDSQTTTCLSGICYKKITRGRYQPEMGCGCPESRRGVKVDCCMSDKCNA 8610083 Mten (A0A194ASE2) IICYKRHASDSQTTTCLSGICYKKITRGRYRPEMGCGCPESRRGVKVDCCMRDKCNG 9110089 Mlat (AOA0G3YLL2) IICYKKEGSDPFTTTCLSGICYKKITHGRFNPEMGCGCPESRRGVQVSCCMIDKCNG $74 \quad 74 \quad 72$

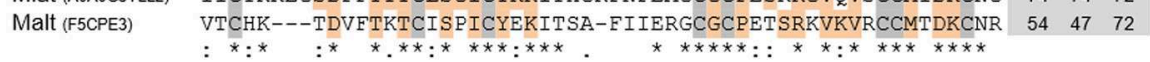

E

Mcor (asax $\operatorname{arc} 7)$

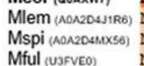

Mful (UIFFM2)

Mten (AOA19arso)

Mdum (COHKo)

Mnig (Pa1167)

Malt (FSCPFO)

Malt (FSCPF 1)

Mmip (Cон(B)
Mnig (Pa1166)

Msur (Aon20s

Mlem (AONzQA4IR)

Milem (АОМ2н6м262)

-

$$
\text { (1) }
$$

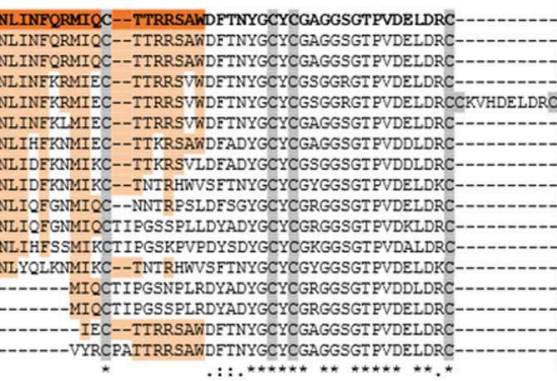

-CKVHDDCYGAAEKYHRCSPRLTLYTSTCSSQTGSVTCKDNGTRCKAFVCNCDRTAALCFGRAPYNRNNENINPNR-CR

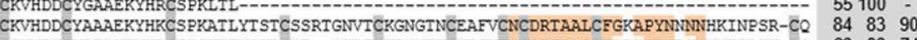
CQVHDKCYDTAKRVHKCFPSVRTYSYDCSE--GKLTCKDNNTKCKDFVCNCDRTAALCFAKIPYNDKNYNIDLKH-CQ $63 \quad 63 \quad 74$

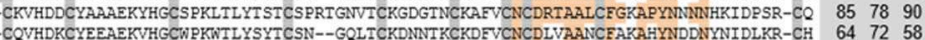
CQVHDKCYEEAEKVHGCNPKWTL YSYTCSN--GQITCKDNNIKCKDFVCNCDLVAANCFAKAHYNDDNYNIDLKR-CH $6472 \quad 58$ CKVHDDCYGEAEKVHGCWPKWTLY Y YDCSN--GQLTCKDNNTKCKDFVCNCDRTAAICFAKAPYDDNNNMINNPR-CQ $7061 \quad 74$ $\begin{array}{lllll}\text { CQVHDKCYDTAKHVCKCSPSMTMYSYDCSE--GKLTCKDNNTKCKDFVCNCDRTAALCFAKAPYNNKNFKIDPTKGCQ } & 63 & 50 & 79 \\ -\end{array}$ CQVHDNCYGEAETVHECDPYWTFYSYECSE--GKLTCKDNNTKCKEFVCNCDREAANCFAKAPYIDSNY----KN-CK 615063 CQAHDKCYTDAYR FYRCWPFLTLYSHTCSN--RKVICRGNTTKCKAFVCNCDRVAANCFAKAPYNKRNY-----NN-CK 605074

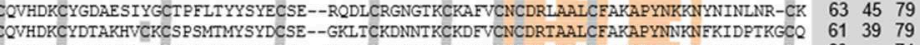
QVHDNCYGEAETVHNCSPYWTPYSYTCSE--GKLICTDNNYVCGIFVCNCDRVAAKCEAKAPYNKKNYNININNR-CK 60 - 74 KVHDDCYGAAEKYHRCSPKLTLYTSTCSSOTGSVICKDNGTKCKAFVCNCDRTAALCFGRAPYNKNNENINPNR-CR KVHDDCYGAAEKYHRCSPKLILYTSTCSSQTGSVTCKDNGTKCKAFVCNCDRTAALCFGRAPYNKNNENINPNR-CR CKVHDDCYGAAEKYHRCSPK

FIGURE 6 | Alignments of M. corallinus toxins mature sequences. Alignment was performed with MUSCLE-EMBL. Conserved cysteines are highlighted in gray. Percentage of identity (\%ID) with reference toxins was calculated using the tool EMBOSS Stretcher for pairwise sequence alignment using either their mature sequence or the specific sequences of the two selected peptides. The reference sequence from $M$. corallinus is in bold and mapped epitopes sequences are highlighted in orange. Aligned sequences are identified by their species initials and UNIPROT number in parenthesis. At the bottom alignment line, an (*) indicates positions which have a single, fully conserved residue; (:) indicates conservation between groups of strongly similar properties; (.) indicates conservation between groups of weakly similar properties. 3FTx toxins alignments are shown in (A-D) and PLA2 alignment is shown in (E).

M. frontalis venom, per $20 \mathrm{~g}$ of mice. Thus, in the assay, we injected a total of $10.5 \mu \mathrm{g}$ of $M$. corallinus venom and $33 \mu \mathrm{g}$ of $M$. frontalis venom, i.e., the absolute amount of $M$. frontalis venom injected in the animals was more than the triple of the amount used for $M$. corallinus venom. $\mathrm{LD}_{50}$ values may vary between venom batches. In the literature and in previous studies from our group, we can find intraperitoneal $\mathrm{LD}_{50}$ values for M. frontalis venom in mice ranging from 4 to $29 \mu \mathrm{g}$ and from 


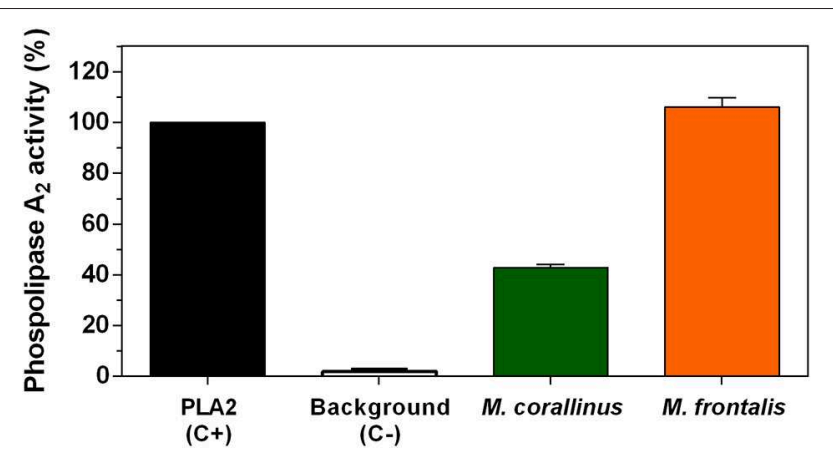

FIGURE 7 | Phospholipase A2 activity. The EnzChek Phospholipase A2 Assay Kit was used to test $M$. corallinus and $M$. frontalis venoms $(2 \mu \mathrm{g})$ according to the manufacturer's instructions. Fluorescence was determined at $490 \mathrm{~nm}$ excitation and $570 \mathrm{~nm}$ emission. Data are represented as the percentage of activity in relation to positive control (purified PLA2 from Apis mellifera). Values represent means $\pm \mathrm{SD}$ of three independent experiments.

5 to $27 \mu \mathrm{g}$ for $M$. corallinus venom (27). As coral venoms are obtained in minor amounts, we chose to use values from the literature rather than establish the LD50 for our venoms experimentally. We chose Tanaka's work as it deals with both $M$. frontalis and $M$. corallinus venoms, allowing to use the same reference for both venoms. However, the real $\mathrm{LD}_{50}$ for our used venoms might have been different. Another possibility is that the immunological response of the host was started with $M$. frontalis venom as antigen, but affinity maturation may have occurred toward M. corallinus peptides. Therefore, in the final sera, anti-peptide antibodies may have prevailed rather than antiM. frontalis venom.

Despite this incomplete neutralization toward $M$. frontalis venom, the present proposal was efficient as a proof-of-concept and there are still many approaches that can be readily used to improve it. The peptides used for substituting $M$. corallinus venom derived from sequences of only 3FTx and PLA2 toxins. These are indeed the most abundant components of Micrurus venoms (13), but there are other venom components that, despite being present in smaller amounts, can have an important role in envenoming, such as 1-amino acid oxidases, metalloproteinases, c-type lectins, etc. (28). As demonstrated by Western Blot results (Figure 5), there are indeed venom protein bands with weaker binding by anti-Ven $\mathrm{fro}_{\text {fro }} / \mathrm{Pep}_{\text {cor }}$ sera. Peptides mimicking epitopes from these other toxin families can be incorporated into the immunization protocol to broaden antibodies reactivity and increase neutralizing potential. Also, as an improvement prospect, the immunization scheme used here can be altered, to represent $M$. frontalis venom in more doses along the program.

The proposed alternative protocol for coral antivenom is still a preliminary work that needs to be further validated, but extrapolating the obtained results to real situations reveals that the presented results are promising. Considering the body mass proportion between a 20 g-mouse and a $70 \mathrm{~kg}$-human, our neutralization assay simulates the inoculation of $36.75 \mathrm{mg}$ of $M$. corallinus venom or $115.5 \mathrm{mg}$ of $M$. frontalis venom to a victim, which exceeds by far the amount of venom a Micrurus snake can inject (8). For antivenom quality control, Brazilian guidelines states that coral antivenom may have a maximum protein amount of $150 \mathrm{mg}$ per $\mathrm{mL}$ that should be able to neutralize $1.5 \mathrm{mg}$ of $M$. frontalis venom. Therefore, to be considered for clinical use, anti-Ven fro $/$ Pep cor sera should be able to neutralize 13.5 $\mu \mathrm{g}$ of $M$. frontalis venom in a neutralization assay [considering that $100 \mu \mathrm{L}$ of rabbit serum contains $1.325 \mathrm{mg}$ of IgG (29)]. As the experimental antivenom (anti-Ven fro $/ \mathrm{Pep}_{\text {cor }}$ sera) was able to neutralize $50 \%$ of the lethality caused by $33 \mu \mathrm{g}$ of $M$. frontalis venom, more than twice the required venom amount in antivenom quality control, we can consider that this protocol may be an interesting approach to coral antivenom production. We must consider carefully the situation illustrated above, since several factors such as different venom susceptibility between mice and humans and the nature of experimental and currently produced antivenom (crude rabbit serum and purified horse Fab'2, respectively) may separate the theoretical observation from reality.

M. frontalis and M. corallinus are the most common coral snakes found in Brazil, but severe accidents with different Micrurus species have been reported in Brazilian territory $(30,31)$. In vitro experiments demonstrated that the currently produced coral antivenom does not recognize adequately some venom components of other Micrurus species and may also poorly neutralize them $(12,32-34)$. Tanaka et al. showed, in 2010, (18) that coral antivenom produced by Butantan was not completely effective in neutralizing enzymatic activities from Brazilian Micrurus venoms. Remarkably, Butantan's coral antivenom was unable to completely neutralize PLA2 activity from $M$. frontalis venom, which is present in the immunization mixture used to produce the antivenom, whereas anti-Ven fro $_{\text {Pep }} / \mathrm{P}_{\text {cor }}$ sera developed in the present work was able to do so. It is also noteworthy in this previous work that Butantan's antivenom was not completely effective in neutralizing lethality from several Micrurus species (M. altirostris. M. lemniscatus, $M$. spixii), including $M$. corallinus, which is also included in the immunization pool. In another work from this same group (34), the immunogenicity of several Micrurus venoms was assessed, aiming at finding experimental basis for broadening coral antivenom reactivity. Monovalent sera toward $M$. altirostris, M. corallinus, M. frontalis, M. lemniscatus, M. spixii and a polyvalent serum were produced in horse. Neutralization assays performed with these produced sera showed that none of the tested immunization approaches were completely efficient, indicating that finding an ideal immunogen for coral antivenom production in Brazil is yet an unsolved issue. Confirming the low cross-neutralization of Brazilian coral antivenom, a clinical case report tells that the available therapeutic antivenom was not completely efficient in reversing the symptoms of patients bitten by Micrurus species other than the ones used in the immunization pool, even when administered early (31).

With this in view, achieving better cross-neutralization becomes an important goal for improving treatment of coral snake envenomed victims (7). Anti-Ven $\mathrm{V}_{\text {fro }} / \mathrm{Pep}_{\mathrm{cor}}$ sera showed good cross-recognition of different relevant Brazilian Micrurus 
A

\section{M. corallinus}
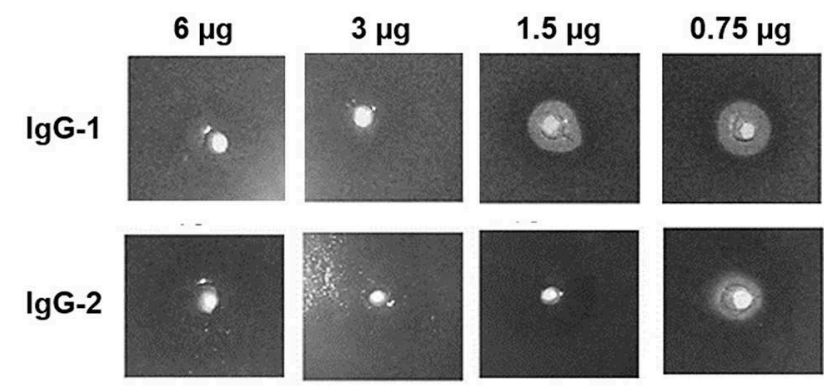

$0.375 \mu \mathrm{g}$
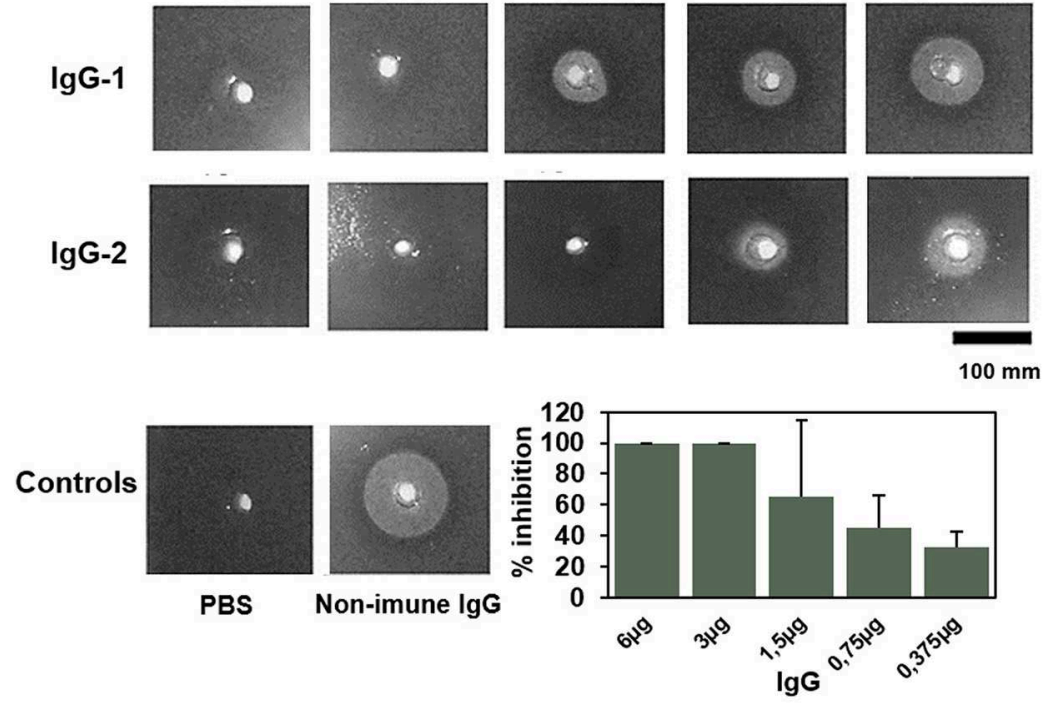

B M. frontalis
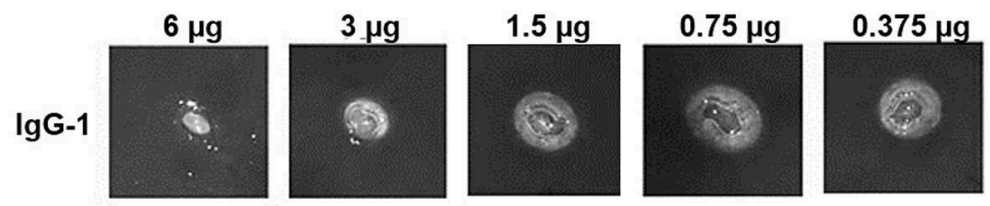

$\lg$ G-2
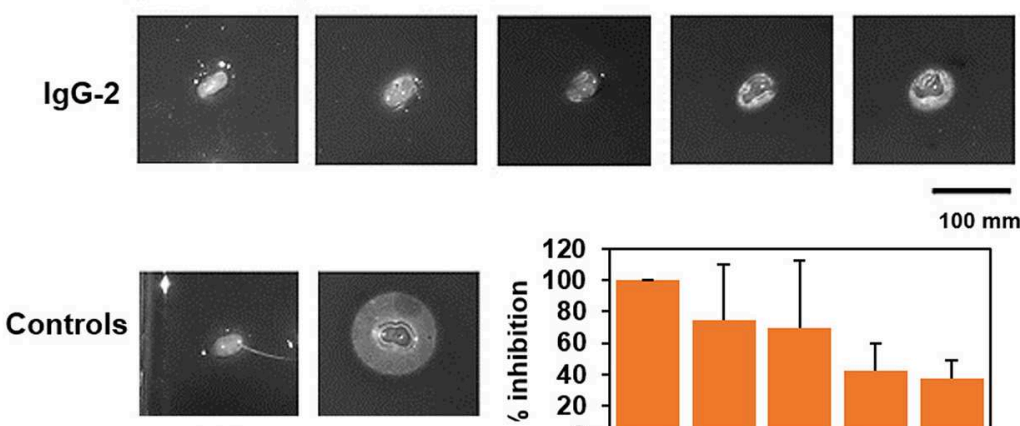

PBS

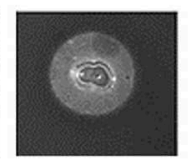

Non-imune IgG

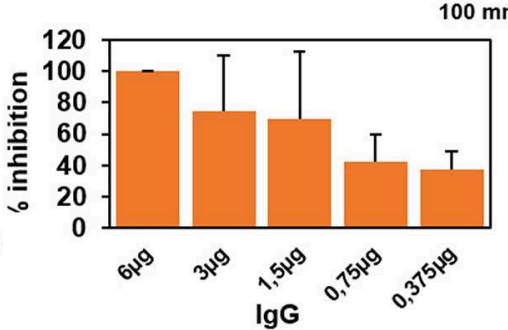

FIGURE 8 | Neutralization of PLA2 activity by anti-Venfro/Pepcor purified lgGs. Neutralization of phospholipase activity of (A) M. frontalis or (B) M. corallinus venom by IgGs anti-Ven fro/Pep cor. An indirect hemolytic assay was performed, using 1 Minimum Phospholisic Dose (MPD) of each venom incubated with different amounts of IgG $(6-0.375 \mu \mathrm{g})$. Non-immune IgG $(6 \mu \mathrm{g})$ incubated with venom (1 MPD) and IgG incubated with PBS instead of venom were used as controls. The percentage of PLA2 activity inhibition was measured and results were plotted in a bar graph. Values are means \pm SEM of two independent assays using the two different rabbit's IgGs.

venoms in ELISA, although this does not necessarily mean crossneutralization of toxic activities (34). But still, this is an important feature of anti-Ven $\mathrm{fro}_{\mathrm{fo}} / \mathrm{Pep}_{\mathrm{cor}}$ sera that must be further explored and improved if necessary.

The main toxin families are conserved among Brazilian Micrurus venoms but there is a large variation in the individual molecules itself, probably reflecting different evolutionary adaptations to habitats, preys and predators (18). Also, less abundant venom components can differ substantially between Micrurus species (28). If an efficient coral antivenom cross-neutralization with different Micrurus species is pursued, a wider variety of molecules should be represented in the immunization mixture used in the antivenom production process. 
TABLE 1 | In vivo protection of anti-Ven fro $_{\text {Pep }} /$ cor $_{\text {sera }}$

\begin{tabular}{|c|c|c|}
\hline Group & Survival/injected & $\%$ Survival \\
\hline \multicolumn{3}{|c|}{ M. corallinus (1.5 LD 50 ) } \\
\hline $\begin{array}{l}\text { Anti- } \\
\text { Ven }_{\text {fro }} / \text { Pep }_{\text {cor }}\end{array}$ & $8 / 8$ & $100 \%$ \\
\hline $\begin{array}{l}\text { Coral antivenom } \\
(\mathrm{C}+)\end{array}$ & $4 / 4$ & $100 \%$ \\
\hline PBS (C-) & $0 / 4$ & $0 \%$ \\
\hline \multicolumn{3}{|c|}{ M. frontalis (1.5 LD $\left.{ }_{50}\right)$} \\
\hline $\begin{array}{l}\text { Anti- } \\
\text { Ven }_{\text {fro }} / \text { Pep }_{\text {cor }}\end{array}$ & $4 / 8$ & $50 \%$ \\
\hline $\begin{array}{l}\text { Coral antivenom } \\
(\mathrm{C}+)\end{array}$ & $4 / 4$ & $100 \%$ \\
\hline PBS (C-) & $0 / 4$ & $0 \%$ \\
\hline
\end{tabular}

Amounts of $M$. corallinus or $M$. frontalis venom, corresponding to 1.5 DL50 were preincubated for $1 \mathrm{~h}$ at $37^{\circ} \mathrm{C}$ with $100 \mu /$ of either PBS (C-), commercial coral antivenom from FUNED $(\mathrm{C}+)$ or anti-Ven fro $_{\text {Pep }}$ cor sera. Animals were injected intraperitoneally, and deaths were recorded $48 \mathrm{~h}$ after injections.

The use of synthetic epitopes to substitute venoms in antivenom production is not novel. Our group has been working on this theme for several years, with promising results $(14,35-38)$. An approach similar to the present work was proposed and validated to produce brown recluse spider antivenom in horses, combining crude venom and a recombinant synthetic antigen, containing epitopes previously mapped in relevant Loxosceles spp. toxins. The combined protocol achieved neutralization parameters comparable to that obtained with venom exclusively and better than using the synthetic antigen alone. This combined protocol reduced by $67 \%$ the need for using crude venom for brown recluse spider antivenom production (39).

Venomics and antivenomics studies are increasing venom composition knowledge (40-42). Immunochemical studies that select potential epitopes to be represented as synthetic peptides or recombinant proteins may also circumvent the lack of immunogenicity observed for some toxins, including the most prevalent 3FTX and PLA2 toxins (43). This increasing knowledge plays an important role in achieving better coverage of coral antivenom, leading to a possible pan-specific antidote toward Micrurus venoms (44).

\section{CONCLUDING REMARKS}

Our results show that it is possible to produce cross-reactive, neutralizing coral antivenom substituting $M$. corallinus venom by

\section{REFERENCES}

1. Chippaux J. Snakebite envenomation turns again into a neglected tropical disease! J Venom Anim Toxins Incl Trop Dis. (2017) 23:38. doi: 10.1186/s40409-017-0127-6

2. Initiative GS. Measuring Snakebite Burdens. (2016) 10-2 p. Available online at: https://www.snakebiteinitiative.org/?page_id=657 (accessed May 02, 2019). synthetic peptides derived from relevant toxin sequences. This implicates in a reduced dependency on venom availability for the production of antivenom and the possibility of manipulating cross-reactivity, by adding other desired toxin-epitopes. This preliminary step can lead to enhanced production of better antivenoms, addressing the important issue of antivenom shortage and may lead toward the development of a panAmerican antivenom.

In addition of the benefits for antivenom fabrication, decreasing the usage of venom for coral antivenom production would allow more venom to be assigned for studies aiming at describing Micrurus envenoming pathophysiology better and should also foment the disclosure of the biotechnological potential of Micrurus venoms.

\section{DATA AVAILABILITY STATEMENT}

The datasets generated for this study are available on request to the corresponding author.

\section{ETHICS STATEMENT}

The animal study was reviewed and approved by Ethics Committee in Animal Experimentation from the Federal University of Minas Gerais.

\section{AUTHOR CONTRIBUTIONS}

CC-O, CF, PH, and CG-D: conception and design of study. KC, LL, DO, and RM: acquisition of data. KC, LL, and CG-D: analysis and interpretation of data. CF and CC-O: contribution of reagents, materials, and analysis tools. CG-D and AP: drafting the article. KC, LL, AP, PH, CC-O, and CG-D: revised critically the final version. All authors approved the final version of the submitted manuscript.

\section{FUNDING}

This research was supported by the Conselho Nacional de Desenvolvimento Científico e Tecnológico, Brazil (CNPq) (Chamada Universal No. 28/2018, Processo: 406163/2018-9), Coordenação de Aperfeiçoamento de Pessoal de Nível Superior, Brazil - CAPES (TOXINOLOGIA No 23038000825/2011-63) and CAPES/COFECUB (Processo: 88881.191812/2018-01) and by Fundação de Amparo a Pesquisa do Estado de Minas Gerais, Brazil (FAPEMIG).
3. FUNASA. Manual de Diagnóstico e Tratamento de Acidentes por Animais Peçonhentos. $2^{a}$ (Brasilia) (2001).

4. Ministério da Saúde do Brasil. SINAN - Sistema de Informação de Agravos de Notificação. (2019). Available online at: http://portalsinan.saude.gov.br/osinan (accessed August 20, 2010).

5. Wood A, Schauben J, Thundiyil J, Kunisaki T, Sollee D, Lewis-Younger C, et al. Review of Eastern coral snake (Micrurus fulvius fulvius) exposures managed 
by the Florida Poison Information Center Network: 1998-2010. Clin Toxicol. (2013) 51:783-8. doi: 10.3109/15563650.2013.828841

6. Bucaretchi F, Hyslop S, Vieira RJ, Toledo AS, Madureira PR, De Capitani EM. Bites by coral snakes (Micrurus spp.) in Campinas, State of São Paulo, southeastern Brazil. Rev Inst Med Trop São Paulo. (2006) 48:141-5. doi: 10.1590/S0036-46652006000300005

7. Bucaretchi F, De Capitani EM, Vieira RJ, Rodrigues CK, Zannin M, Da Silva NJ, et al. Coral snake bites (Micrurus spp.) in Brazil: A review of literature reports. Clin Toxicol. (2016) 54:222-34. doi: 10.3109/15563650.2015.1135337

8. Carvalho AV, David CF, Pessoa ADM, Da Silva NJ Jr. Um estudo do rendimento do veneno de cobras corais brasileiras e seu uso na avaliação do soro antielapídico. Sci Med. (2014) 24:142. doi: 10.15448/1980-6108.2014.2.16119

9. Morais-zani K De, Serino-silva C, Galizio C, Jorge L, Falararo J, Maria M, et al. Does the administration of pilocarpine prior to venom milking in $\mathrm{fl}$ uence the composition of Micrurus corallinus venom? J Proteomics. (2018) 174:17-27. doi: 10.1016/j.jprot.2017.12.010

10. De Roodt AR, Dolab JA, Galarce PP, Gould E, Litwin S, Dokmetjian JC, et al. A study on the venom yield of venomous snake species from Argentina. Toxicon. (1998) 36:1949-57. doi: 10.1016/S0041-0101(98)00119-6

11. Mendes GF, Stuginski DR, Loibel SMC, Morais-Zani K, de Rocha MMT, da Fernandes W, et al. Factors that can influence the survival rates of coral snakes (Micrurus corallinus) for antivenom production. J Anim Sci. (2018) 97:972-80. doi: $10.1093 /$ jas/sky467

12. Ramos HR, Vassão RC, de Roodt AR, Santos e Silva EC, Mirtschin P, Ho PL, et al. Cross neutralization of coral snake venoms by commercial Australian snake antivenoms. Clin Toxicol. (2016) 3650:1-10. doi: 10.1080/15563650.2016.1222615

13. Leão LI, Ho PL, Junqueira-de-Azevedo IDLM. Transcriptomic basis for an antiserum against Micrurus corallinus (coral snake) venom. BMC Genomics. (2009) 10:112. doi: 10.1186/1471-2164-10-112

14. Castro KL, Duarte CG, Ramos HR, Machado De Avila RA, Schneider FS, Oliveira D, et al. Identification and characterization of B-cell epitopes of 3FTx and PLA(2) toxins from Micrurus corallinus snake venom. Toxicon. (2015) 93:51-60. doi: 10.1016/j.toxicon.2014.10.015

15. Ramos HR, Junqueira-de-Azevedo IDLM, Novo JB, Castro K, Duarte CG, Machado-de-Ávila RA, et al. A heterologous multiepitope DNA prime/recombinant protein boost immunisation strategy for the development of an antiserum against Micrurus corallinus (Coral Snake) venom. PLoS Negl Trop Dis. (2016) 10:e0004484. doi: 10.1371/journal.pntd.0004484

16. Lowry OH, Rosebrough NJ, Farr L, Randall RJ. Protein measurement with the Folin Phenol reagent. J Biol Chem. (1951) 193:265-75.

17. Gutiérrez JM, Avila C, Rojas E, Cerdas L. An alternative in vitro method for testing the potency of the polyvalent antivenom produced in Costa Rica. Toxicon. (1988) 26:411-3. doi: 10.1016/0041-0101(88)9 0010-4

18. Tanaka GD, Furtado MDFD, Portaro FCV, Sant'Anna OA, Tambourgi DV. Diversity of Micrurus snake species related to their venom toxic effects and the prospective of antivenom neutralization. PLoS Negl Trop Dis. (2010) 4:e622. doi: 10.1371/journal.pntd.0000622

19. Ministério da Saúde do Brasil. Protocolo Clínico. Acidente por serpente da família Elapidae, gêneros Micrurus e Leptomicrurus "Coral verdadeira." (Brasilia) (2014). Available online at: http://www.saude.gov.br

20. Gutiérrez JM, Burnouf T, Harrison RA, Calvete JJ, Kuch U, Warrell A. A multicomponent strategy to improve the availability of antivenom for treating snakebite envenoming. Bull World Health Organ. (2014) 92:526-32. doi: 10.2471/BLT.13.132431

21. Fan HW, Monteiro WM. History and perspectives on how to ensure antivenom accessibility in the most remote areas in Brazil. Toxicon. (2018) 151:15-23. doi: 10.1016/j.toxicon.2018.06.070

22. Gutiérrez J. Global availability of antivenoms: the relevance of public manufacturing laboratories. Toxins. (2018) 11:5. doi: 10.3390/toxins 11010005

23. Squaiella-Baptistão CC, Sant'Anna OA, Marcelino JR, Tambourgi DV. The history of antivenoms development: beyond Calmette and Vital Brazil. Toxicon. (2018) 150:86-95. doi: 10.1016/j.toxicon.2018.05.008

24. Araujo HP, Bourguignon SC, Boller MA, Dias AA, Lucas EPR, Santos IC, et al. Potency evaluation of antivenoms in Brazil: the national control laboratory experience between 2000 and 2006. Toxicon. (2008) 51:502-14. doi: 10.1016/j.toxicon.2007.11.002
25. Gutiérrez J, Solano G, Pla D, Herrera M, Segura Á, Vargas M, et al. Preclinical evaluation of the efficacy of antivenoms for snakebite envenoming: state-of-the-art and challenges ahead. Toxins. (2017) 9:163. doi: 10.3390/toxins 9050163

26. Rubinstein ND, Mayrose I, Martz E, Pupko T. Epitopia: a web-server for predicting B-cell epitopes. BMC Bioinformatics. (2009) 10:287. doi: 10.1186/1471-2105-10-287

27. Sanz L, Pla D, Pérez A, Rodríguez Y, Zavaleta A, Salas M, et al. Venomic analysis of the poorly studied desert coral snake, Micrurus tschudii tschudii, supports the 3FTx/PLA2 dichotomy across Micrurus venoms. Toxins. (2016) 8:178. doi: $10.3390 /$ toxins 8060178

28. Aird S, da Silva N, Qiu L, Villar-Briones A, Saddi V, Pires de Campos Telles $\mathrm{M}$, et al. Coralsnake venomics: analyses of venom gland transcriptomes and proteomes of six Brazilian Taxa. Toxins. (2017) 9:187. doi: 10.3390/toxins9060187

29. Rayner LE, Kadkhodayi-Kholghi N, Heenan RK, Gor J, Dalby PA, Perkins SJ. The solution structure of rabbit igg accounts for its interactions with the $\mathrm{Fc}$ receptor and complement $\mathrm{Clq}$ and its conformational stability. J Mol Biol. (2013) 425:506-23. doi: 10.1016/j.jmb.2012.11.019

30. da Silva IM, Bernal JC, Gonçalves Bisneto PF, Tavares AM, de Moura VM, Monteiro-Junior CS, et al. Snakebite by Micrurus averyi (Schmidt, 1939) in the Brazilian Amazon basin: Case report. Toxicon. (2018) 141:51-4. doi: 10.1016/j.toxicon.2017.11.012

31. Pardal PPDO, Pardal JSDO, Gadelha MADC, Rodrigues LDS, Feitosa DT, Prudente ALDC, et al. Envenomation by Micrurus coral snakes in the Brazilian Amazon region: report of two cases. Rev Inst Med Trop São Paulo. (2010) 52:333-7. doi: 10.1590/S0036-466520100006 00009

32. Ciscotto PHC, Rates B, Silva DAF, Richardson M, Silva LP, Andrade $\mathrm{H}$, et al. Venomic analysis and evaluation of antivenom cross-reactivity of South American Micrurus species. J Proteomics. (2011) 74:1810-25. doi: 10.1016/j.jprot.2011.07.011

33. De Abreu VA, Leite GB, Oliveira CB, Hyslop S, Furtado MDFD, Simioni LR. Neurotoxicity of Micrurus altirostris (Uruguayan coral snake) venom and its neutralization by commercial coral snake antivenom and specific antiserum raised in rabbits. Clin Toxicol. (2008) 46:519-27. doi: $10.1080 / 15563650701647405$

34. Tanaka GD, Sant'Anna OA, Marcelino JR, Lustoza da Luz AC, Teixeira da Rocha MM, Tambourgi DV. Micrurus snake species: venom immunogenicity, antiserum cross-reactivity and neutralization potential. Toxicon. (2016) 117:59-68. doi: 10.1016/j.toxicon.2016.03.020

35. Alvarenga LM, Diniz CR, Granier C, Chavez-Olortegui C. Induction of neutralizing antibodies against Tityus serrulatus scorpion toxins by immunization with a mixture of defined synthetic epitopes. Toxicon. (2002) 40:89-95. doi: 10.1016/S0041-0101(01)00197-0

36. Mendes TM, Oliveira D, Figueiredo LFM, Machado-de-Avila RA, Duarte CG, Dias-Lopes C, et al. Generation and characterization of a recombinant chimeric protein $(\mathrm{rCpLi})$ consisting of B-cell epitopes of a dermonecrotic protein from Loxosceles intermedia spider venom. Vaccine. (2013) 31:274955. doi: 10.1016/j.vaccine.2013.03.048

37. Molina DA, Guerra-duarte C, Naves DL, Souza D, Costal-oliveira F, Reis $\mathrm{G}$, et al. Identi fi cation of a linear B-cell epitope in the catalytic domain of bothropasin, a metalloproteinase from Bothrops jararaca snake venom. Mol Immunol. (2018) 104:20-6. doi: 10.1016/j.molimm.2018. 10.019

38. Dias-Lopes C, Guimarães G, Felicori L, Fernandes P, Emery L, Kalapothakis $\mathrm{E}$, et al. A protective immune response against lethal, dermonecrotic and hemorrhagic effects of Loxosceles intermedia venom elicited by a 27-residue peptide. Toxicon. (2010) 55:481-7. doi: 10.1016/j.toxicon.2009. 09.019

39. Figueiredo FM, Dias-lopes C, Alvarenga LM, Mccormack J, Mendes TM, Avila RAM, et al. Innovative immunization protocols using chimeric recombinant protein for the production of polyspeci fi $c$ loxoscelic antivenom in horses. Toxicon. (2014) 86:59-67. doi: 10.1016/j.toxicon.2014. 05.007

40. Calvete JJ. Venomics: integrative venom proteomics and beyond. Biochem J. (2017) 474:611-34. doi: 10.1042/BCJ20160577

41. Calvete JJ, Gutiérrez JM, Sanz L, Pla D, Lomonte B. Chapter 7: Antivenomics: a proteomics tool for studying the immunoreactivity of antivenoms. In: J. Kool 
and W. M. A. Niessen, editors. Analyzing Biomolecular Interactions by Mass Spectrometry. (2015). p. 227 -39. doi: 10.1002/9783527673391.ch7

42. Gutiérrez JM, Lomonte B, Sanz L, Calvete JJ, Pla D, María J, et al. Immunological profile of antivenoms: preclinical analysis of the efficacy of a polyspecific antivenom through antivenomics and neutralization assays. $J$ Proteomics. (2014) 105:340-50. doi: 10.1016/j.jprot.2014.02.021

43. Laustsen AH. Guiding recombinant antivenom development by omics technologies. N Biotechnol. (2018) 45:19-27. doi: 10.1016/j.nbt.2017.05.005

44. Lomonte B, Rey-Suárez P, Fernández J, Sasa M, Pla D, Vargas N, et al. Venoms of Micrurus coral snakes: evolutionary trends in compositional patterns emerging from proteomic analyses. Toxicon. (2016) 122:7-25. doi: 10.1016/j.toxicon.2016.09.008
Conflict of Interest: The authors declare that the research was conducted in the absence of any commercial or financial relationships that could be construed as a potential conflict of interest.

Copyright $\odot 2019$ de Castro, Lopes-de-Souza, de Oliveira, Machado-de-Ávila, Paiva, de Freitas, Ho, Chávez-Olórtegui and Guerra-Duarte. This is an open-access article distributed under the terms of the Creative Commons Attribution License (CC BY).

The use, distribution or reproduction in other forums is permitted, provided the original author(s) and the copyright owner(s) are credited and that the original publication in this journal is cited, in accordance with accepted academic practice. No use, distribution or reproduction is permitted which does not comply with these terms. 